\title{
Determination of significant factors in high-shear granulation process of sucrose with aqueous solution of sodium lauryl sulphate using partial least square regression approach
}

\author{
Marina Todorovska Ackovska ${ }^{1}$, Nikola Geskovski ${ }^{2}$, Katerina Goracinova ${ }^{2,3 *}$ \\ ${ }^{1}$ Department for Production of Cephalosporines, Alkaloid AD Skopje, \\ Blvd. Partizanski Odredi 98A, 1000 Skopje, North Macedonia \\ ${ }^{2}$ Institute of Pharmaceutical Technology, Faculty of Pharmacy, \\ Ss. Cyril \& Methodius University, Mother Teresa 47, 1000 Skopje, North Macedonia \\ ${ }^{3}$ College of Pharmacy, Qatar University, PO Box 2713, Doha, Qatar
}

Received: January 2019; Accepted: February 2019

\begin{abstract}
Sucrose as one of the most commonly used raw materials in pediatric formulations is soluble and sticky excipient and its manipulation in high shear granulators may be very difficult.

Therefore, to determine the correct amount of liquid binder is very important because it falls in a very narrow range and may vary due to small variations in the material properties or environmental conditions. The possibility of using the sugar as powder for granulation may be very challenging because of solubility and moisture adsorption properties of crystalline sugar, especially if the binder solution is water.

The aim of this study was trying to solve these problems and produce sucrose granules using high share granulation and water as a binding liquid, with properties required for final product good performance.

By reducing the sucrose particle size and improving the uniformity of the size distribution, the differences of the processes of nucleation and growth for small and large particles might be reduced.

According to the variable importance or VIP scores from the developed partial least square (PLS) model, raw material particle size is as influential variable as the quantity and composition of the granulation liquid (Gra), granulation time (Grn) and impeller rate (Imp).
\end{abstract}

Keywords: sucrose, particle size distribution, high-shear granulation, partial least square

\section{Introduction}

Sucrose is one of the most commonly used raw materials in pediatric formulations and it is usually involved in granulation processes with different purposes.

In particular, it can act as a diluent, binder but also as a taste masking agent, sweetener and for production of sugar pellets for drug layering and sustained or extended dosage form design.

Sucrose is soluble and sticky excipient and its manipulation in high shear granulators may be very difficult because it can adhere to the mixer walls or lead to an uncontrolled granule growth. The effects of the process variables in granule growth are related to the properties of the material for granulation; for ex. the

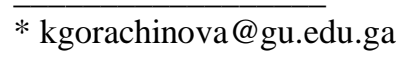


particle size and the solubility in the granulation liquid as the most important one. When the material for granulation is soluble in water, the amount of liquid for granulation has to be lower. However, the amount of liquid binder depends not only on the physico-chemical properties of the raw material for granulation, but also on the raw material-liquid binder interaction and the process variables like impeller speed, granulation liquid addition rate, wet massing time etc. (Cantor et al., 2008). Therefore, to determine the correct amount of liquid binder is very difficult task as it falls in a very narrow range and may vary due to small variations in the material properties or environmental conditions. In humid conditions, moisture adsorption on the sucrose particle surface can induce deliquescence and formation of liquid viscous bridges which cause sticky behavior of the wet mass (Santomaso et al., 2017).

Although the process of wet granulation is used in the pharmaceutical industry for a very long time, it remains a highly empirical process and establishing of the end-point of granulation is usually verified by observation and experience (Bariani et al., 2008). Also, the influence of the powder for granulation (formula) properties on the granule properties remains under researched. Wet granulation rate processes that occur in high-share industrial granulators may be divided into three main stages: wetting and nucleation, consolidation and growth, and granule attrition and breakage (Litster and Ennis, 2004). The type, quantity, hygroscopicity, primary particle size and shape, particle size distribution, water-solid interactions as well as some important process variables (i.e. impeller speed, liquid flow rate and amount) will influence the granule growth behavior. Two mechanisms of nucleation are proposed, the distribution and immersion mechanism. The nucleation regime has an important role in dictating the properties of the final granules and among the other factors it depends on properties of the powder for granulation, the particle size and particle size distribution (PSD). Further, granules are preferentially formed by liquid penetration and partially by coalescence (van den Dries and Vromans, 2004). In addition, substances with a high wettability and smaller particle size will form granules at a higher rate (Miyamoto et al., 1998a). Having the background, the inhomogeneity in distribution of the Gra in the granulation bed might be substantial in a case of wide PSD of a highly soluble granulation material (Miyamoto et al., 1995; Miyamoto et al., 1998b). During the granule growth, the binder liquid from the pores inside the agglomerate is redistributed to the pores formed by the adherence of new particles in order liquid bridges to be formed. Only small particles can penetrate the partially formed granule and adhere to the wetted surface. Large one will not be able to enter the partially saturated pores and therefore will not be able to bind. In addition, the porous surface of the large particles cannot not be saturated as fast as the surface of the small particles in order the liquid bridges to be formed and granule growth to be initiated. Therefore, a porous granular surface can be considered dry for large particles and wet for smaller particles. This leads to preferential layering of smaller particles upon the large one, inducing heterogeneity of the distribution of the materials in the granular bed, granules with a wide size distribution and different mechanical strength (van den Dries and Vromans, 2004).

Having in mind the crystalline sugar solubility and moisture adsorption properties, the possibility of using the largest possible amounts of sugar or 100\% of sugar as powder for granulation may be very challenging, especially if the binder solution is water. Our aim was to try to solve these problems and produce sucrose granules using high share granulation and water as a binding liquid, with properties required for final product good performance, using a robust process easily scalable to industrial scale. Therefore, we hypothesized that the factors of crucial importance for the required quality of the granules would be particle size and PSD of the material for granulation. By reducing the sucrose particle size and improving the uniformity of the size distribution, the differences of the processes of nucleation and growth for small and large particles might be reduced. The powder bed surface area will grow substantially by the particle size reduction, contributing to improvement of the uniformity of water distribution, wetting saturation, granule formation and granule growth. Further, the effect of particle size and distribution on the granule properties will be evaluated under different operating conditions of the high share granulatior (Imp, chopper rate (Chp), Grn), with varying amounts of Gra. The interaction of the drying time with various operating conditions will be also evaluated. The models will be developed using PLS regression. PLS is recommended in the literature as suitable approach for modeling of large processes, with serious multicolinearity, numerous variables and specific information for different parts of the processing which will be lost if all data are not examined simultaneously (Westerhuis, 1997; Westerhuis and Coenegracht, 1997).

\section{Material and methods}

\section{Materials}

All used materials were of analytical grade, Saccharum album/sucrose/ (Studen-Agrana, Bosnia and Hercegovina), Kolliphor SLS Fine/Sodium lauryl sulphate/(SLS) (BASF, Germany), Aqua purificata (System for production of Purified Water WERNER, Alkaloid).

\section{Methods}

\section{Sucrose preparation}

Sucrose was milled in a two-stage process. The first milling phase was performed on D6A industrial mill (Fitz Patrick, USA) with sieve No.1531-0065; 1532-0050; 
1532-0033; 1532-0024; 1532-0020 and speed 4000rpm/40rpm. The milled sucrose was transferred to grinder GRINDOMIX GM200 (Retsch, Germany) for the second stage milling in order to achieve additional size reduction. Milling time on the grinder was adjusted according to the desired particle size at $2 \mathrm{~min}$ and $10 \mathrm{sec}$ with speed $8000 \mathrm{rpm}$.

\section{Method of preparation of sucrose granules}

The wet granulation experiments have been performed with a laboratory high-shear mixer granulator Diosna P1/6 (DIOSNA Dierks \& Söhne GmbH, Germany) with a horizontal bowl with a capacity of 4L.

The bowl was loaded with a specified quantity of milled sucrose and the impeller and chopper were turned on for a dry run before the binder solution (1-5\% aqueous solution of SLS) was added through the opening on the mixer lid.

The speed of the impeller was set from 180-200rpm and the speed of the chopper was set from 1500-2000rpm.

After granulation, the granules were sieved through screen 6350 on conical milling equipment U5 (Quadro Comil, Canada) and dried at a temperature of $50{ }^{\circ} \mathrm{C}$ in a laboratory tray oven MOV 212S (Panasonic, Japan).

The wet granules were dried till the moisture content was $\leq 0.5 \%$.

After drying, the granules were sieved through screen 1016 on conical milling equipment U5 (Quadro Comil, Canada).

\section{Moisture determination}

The moisture content was determined by using a halogen moisture analyzer HS153 (Mettler Toledo, Germany) as a common method for determining moisture content via loss on drying.

Drying temperature on the moisture analyzer was set on $105{ }^{\circ} \mathrm{C}$ and the switch-off criterion (drying rate threshold) was set on $1 \mathrm{mg} / 50 \mathrm{~s}$. The result is expressed as per cent $\mathrm{m} / \mathrm{m} \%$ Moisture Content (\%MC) and is calculated by using the following Eq.1:

$$
M C(\%)=100(W W-D W) / W W
$$

where MC is the measured Moisture Content; WW is the wet weight; and DW is the dry weight.

\section{Particle characterization}

Particle size distribution (PSD) analysis. The PSD analysis of the dried samples were obtained by sieving using a vibratory sieve shaker AS 200 Control (Retsch, Germany). The following sieve size class $(\mathrm{mm})$ were used: $0.080 ; 0.150 ; 0.250 ; 0.315 ; 0.500$. The sample quantity was weighted and then was loaded on the assembled sieves. Sieving duration was set on 5minutes and the amplitude of vibration was set on $1.5 \mathrm{~mm}$.
Morphological analysis. The morphological analysis was performed on static image analysis system Morphologi G3 (Malvern, UK). For image analysis of dried samples 2.5x: $100 \mu \mathrm{m}-1000 \mu \mathrm{m}$ (nominal) and 5x: $25 \mu \mathrm{m}-420 \mu \mathrm{m}$ objectives (nominal) were used. The milled sucrose samples were dispersed onto the glass slides with an integrated dry powder disperser using 1 bar dispersion pressure.

Bulk / tapped density and Carr index. Bulk density was determined by a measurement in a graduated $100 \mathrm{~mL}$ cylinder readable to $1 \mathrm{~mL}$ according to a method 2.9.34. described in Ph.Eur. 9.0.

After 1250 taps on Erweka SVM 102 (Erweka $\mathrm{GmbH}$, Germany) was determined the tapped density according to a method 2.9.34. described in Ph. Eur. 9.0 and Carr index was calculated by using the following Eq. 2:

$$
C I=100(V 0-V f) / V 0
$$

where V0 is the unsettled apparent volume (bulk volume); and $\mathrm{Vf}$ is the final tapped volume.

Angle of repose and flow rate. In each experiment the angle of repose and flow rate was determinate on GTB (Erweka GmbH, Germany).

For parameter angle of repose a funnel with nozzle size $10 \mathrm{~mm}$ was used.

Sample with predefined volume $(100 \mathrm{~mL})$ was loaded in the funnel, after that the funnel nozzle was opened and the granules were let to settle onto a circular plate with a defined surface area, thus forming a cone. An integrated driven laser measured the side wall of the built-up cone and the actual angle was calculated and displayed. The test was performed three times and an average value of angle of repose was calculated.

The same funnel with nozzle size $10 \mathrm{~mm}$ was used for measurement of the flow rate.

Sample with predefined volume $(100 \mathrm{~mL})$ was loaded in the funnel, and afterwards the funnel nozzle was opened and the time taken to empty the funnel was measured. The measured time was displayed. The test was performed three times and an average value of flow rate was calculated.

\section{Statistical analysis}

Partial least square (PLS) methodology was used to analyze the correlation among selected process and formulation factors (independent variables - Table 1) and the properties of the granules and the granulation end point (dependent variables). The analysis was performed using validated statistical software Simca 15 and Modde 10 (Sartorius Stedim Biotech, Germany). VIP score was used to point out the process and formulation factors which have significant contribution to the model and therefore demonstrate notable influence over the dependent variables. 


\section{Results and discussion}

Granulation process is a crucial step for the quality of the final product. Granules are often required to prevent segregation of critical components in a powder mixture by reducing the difference in size and density between different powders and they are usually involved in several subsequent process steps like mixing, compression and packaging during the end product manufacturing. Therefore, granules have to be carefully designed using well-defined manufacture processes with high reproducibility of the critical product attributes. Welldesigned process can create homogenous granules having similar size and composition, thus minimizing the segregation phenomena. High share granulation is very efficient granulation process with automatic monitoring of the process parameters (i.e. impeller speed, liquid flow rate and amount) and of line and on line product parameters survey (particle size and particle size distribution). However, the focus of the research has been primarily at the end-point determination and the correlation of the material for granulation characteristics with the granulation properties and the granulation endpoint have been rarely considered. However, nucleation and granule growth depend upon the primary material properties and closer control of the starting material characteristics will improve the efficacy and reproducibility of the granulation process. We aimed to produce sucrose granules with increased size uniformity, improved homogeneity and mechanical properties. Having in mind that the primary material particle size and particle size distribution determines the granule growth and mechanical properties of the granules as well as the degree of granule inhomogeneity by dictating the layering growth mechanism we decided to design sets of granulation experiments using sucrose with different particle size $(\mathrm{d} 10, \mathrm{~d} 50, \mathrm{~d} 90)$ in order to evaluate these effects. Water with different concentration of SLS was used for granulation. Besides the formulation factors we varied the processing factors, impeller rate, granulation time and chopper rate, in an attempt to establish correlation of the starting material characteristics and process parameters on the granules' characteristics. The dependent variables were bulk density, tapped density, Carr index, angle of repose, and particle size of the granules. PLS model was used to investigate how selected formulation and process factors influence the granulation properties and the end point of granulation.

Table 1. Independent factors and their levels/values in the set of experiments

\begin{tabular}{lllllllllll}
\hline \hline $\begin{array}{l}\text { Serie } \\
\text { No }\end{array}$ & $\begin{array}{l}\text { SLS } \\
(\mathrm{g})\end{array}$ & $\begin{array}{l}\text { Gra } \\
(\mathrm{g})\end{array}$ & $\begin{array}{c}\text { Imp } \\
(\mathrm{rpm})\end{array}$ & $\begin{array}{l}\text { Chp } \\
(\mathrm{rpm})\end{array}$ & $\begin{array}{l}\text { Grn } \\
(\mathrm{min})\end{array}$ & $\begin{array}{l}\text { Dry } \\
(\mathrm{min})\end{array}$ & S d10 & S d50 & S d90 & SPAN \\
\hline $1 \_1$ & 2 & 14.4 & 180 & 2000 & 7 & 60 & 57.76 & 279.82 & 614.86 & 1.99 \\
$5 \_1$ & 2 & 14.4 & 180 & 1500 & 7 & 60 & 69.75 & 332.19 & 716.71 & 1.95 \\
6_1 & 2 & 14.4 & 180 & 1500 & 8 & 60 & 50.34 & 238.63 & 538.04 & 2.05 \\
$7 \_1$ & 2 & 14.4 & 180 & 1500 & 8 & 90 & 17.00 & 90 & 230 & 2.36 \\
$7 \_2$ & 4 & 28.8 & 180 & 1500 & 8 & 120 & 17.00 & 90 & 230 & 2.36 \\
$7 \_3$ & 6 & 43.2 & 180 & 1500 & 5 & 120 & 17.00 & 90 & 230 & 2.36 \\
$7 \_4$ & 10 & 72.0 & 200 & 1500 & 2 & 180 & 17.00 & 90 & 230 & 2.36 \\
$8 \_1$ & 6 & 43.2 & 200 & 1500 & 5 & 120 & 12.00 & 62 & 157 & 2.30 \\
$8 \_2$ & 10 & 72.0 & 200 & 1500 & 5 & 210 & 12.00 & 62 & 157 & 2.30 \\
$8 \_3$ & 4 & 28.8 & 200 & 1500 & 5 & 80 & 12.00 & 62 & 157 & 2.30 \\
$9 \_1$ & 10 & 72.0 & 200 & 1500 & 3 & 180 & 13.00 & 63 & 145 & 2.09 \\
$10 \_1$ & 10 & 72.0 & 200 & 1500 & 2 & 120 & 57.76 & 279.82 & 614.86 & 1.99 \\
$10 \_2$ & 6 & 43.2 & 200 & 1500 & 3 & 105 & 69.75 & 332.19 & 716.71 & 1.95
\end{tabular}

SLS - sodium lauryl sulfate; Gra - granulation liquid; Imp - impeller rate; Chp - chopper rate; Grn - granulation time; Dry - drying time; S d10 - sucrose d10; S d50 - sucrose d50; S d90 - sucrose d90. 


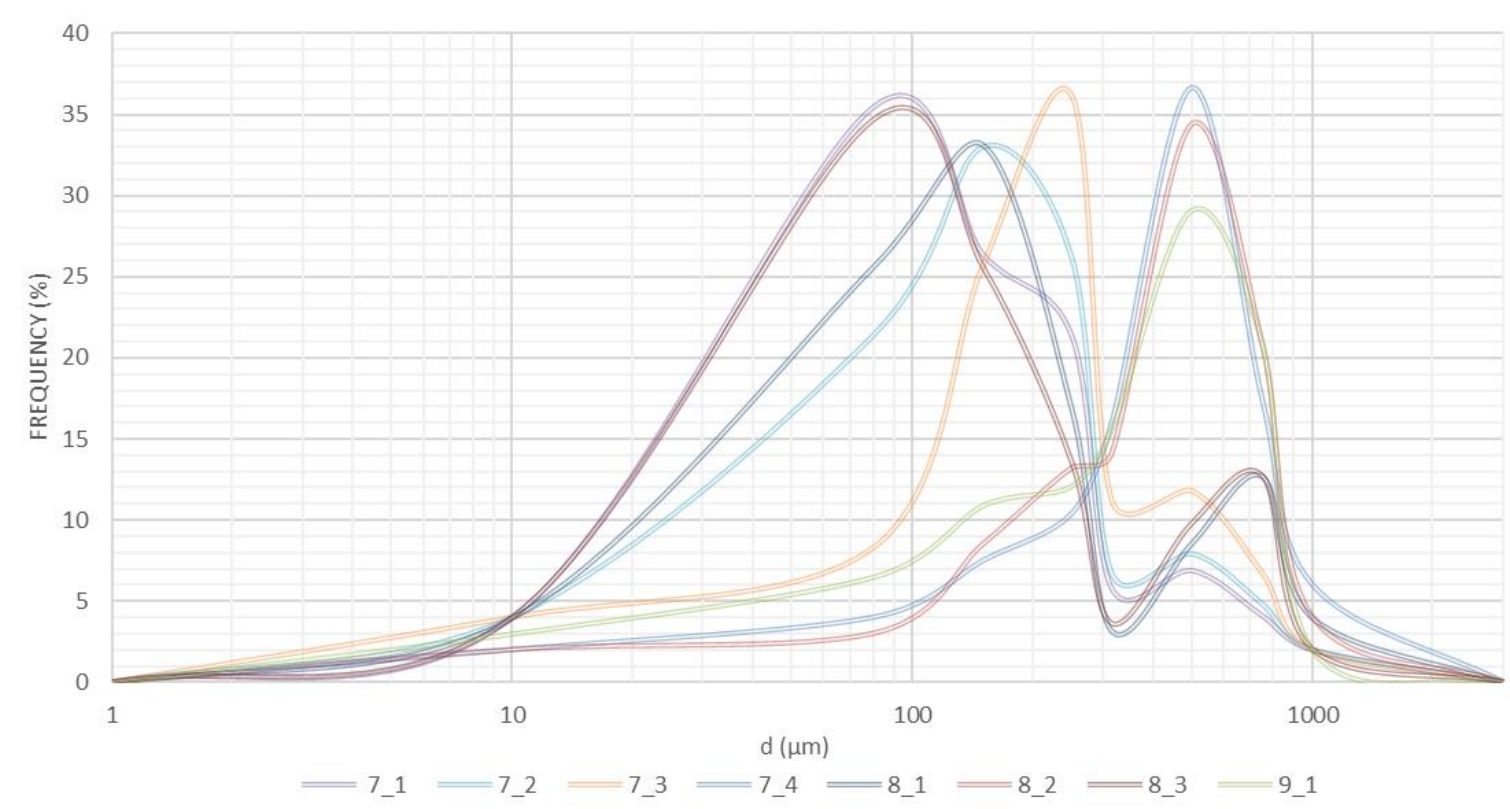

Fig. 1. Comparative presentation of particle size distribution of the prepared sucrose granules.

Table 1 shows the selected independent factors and their levels/values that were evaluated in the set of 13 experiments. In all experiments, the same batch of sucrose was used. The sucrose for batches 7_1,7_2, 7_3, 7_4 is comminuted using Fitz Patrick equipped with a sieve 1532-0024, and for samples 8_1, 8_2,8_3 and 9_1 Fitz Patrick was equipped with a sieve 1532-0020. In order to achieve additional size reduction for samples $8 \_1,8 \_2$, $8 \_3$ and 9_1 the milled sucrose was transferred to grinder GRINDOMIX GM200 (Retsch, Germany) for the second stage milling. Additionally, sample 9_1 is sieved through $315 \mu \mathrm{m}$ sieve before granulation. PLS analysis was performed in order to identify the main factors related to granule properties. The PLS model extracted 5 significant components that explained $76 \%$ of the variance (R2Ycum $=0.76)$. The PLS analysis extracted one significant component (the first PLS component) that explained 88\% and $87 \%$ of the variance in the model for the bulk (BD) and tapped density (TD), with very good predictivity of $\mathrm{Q} 2=0.81$ and 0.80 , respectively. $54 \%$ of the variance for loss on drying (LOD) PLS model was explained with the first PLS component and to overall $75 \%$ with the second PLS component, with predicitivity higher than $0.81 .83 \%$ and $89 \%$ of the model variation for flow rate (FR) and angle of repose (AR) was explained in the third PLS component with predictivity of 0.4 and 0.8 , respectively. More than $80 \%$ of the variation of the model variation for the granule diameters and SPAN value was explained within the second PLS component with predictivity of 0.8 . Only the Carr index model variation was explained with lower predictivity of 0.35 within the third $(60 \%)$ and fourth $(77 \%)$ PLS component.
As previously mentioned, thirteen experiments were used as a combination of different levels of the evaluated factors. However, only eleven were included in the statistical analysis due to the development of over massed systems for two samples (10_1; 10_2) of noncomminuted sucrose when higher quantities of water for granulation was used. The particle size distribution of the samples included in the statistical evaluation is presented on Figure 1.

Considering that the only difference between the samples was the particle size of the raw material, we may say that high shear granulation end-point depends on the particle size of the raw material. The process of high share granulation is performed within a few minutes in the same piece of equipment, but it needs to be controlled with care as the transition from optimum granule to over massed system can progress rapidly. Probably, the smaller surface area of samples with larger particle size does not allow adsorption of increased quantities of Gra, which is a prerequisite for improved granulation. In fact, non-comminuted sucrose (NCS) granulation with smaller amounts of Gra (14.4 and $25 \mathrm{~mL}$ ) resulted in poor granule growth. Large particles were not included in the process of nucleation as their porous surface cannot not be saturated as fast as the surface of the small particles in order the liquid bridges to be formed and granule growth to be initiated. During the granulation process of NCS, layering of smaller particles upon the large one was the main mechanism of granule growth, which results in heterogeneity of the distribution of the materials in the granular bed and granules with low mechanical strength (van den Dries and Vromans, 2004). Similar growth 


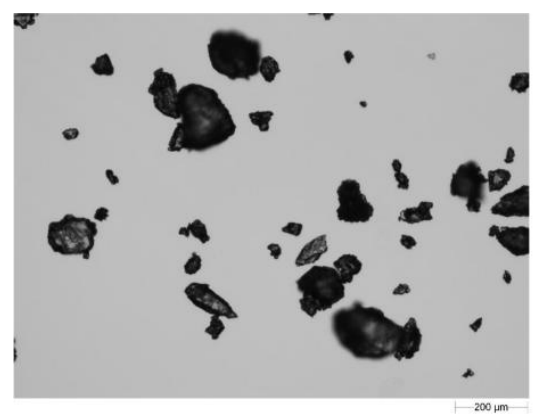

a)

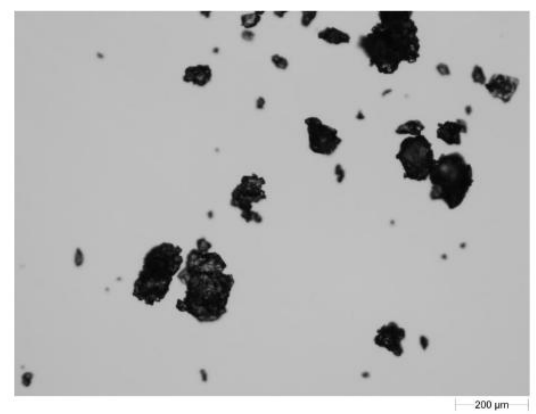

b)

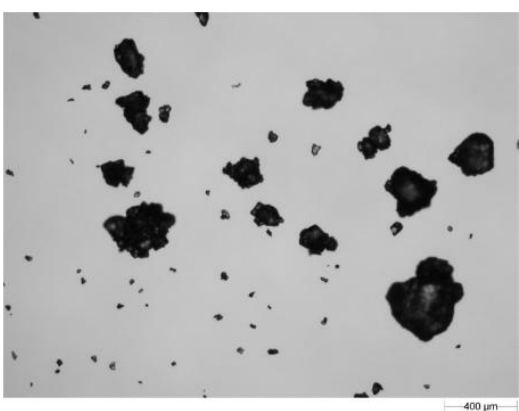

c)

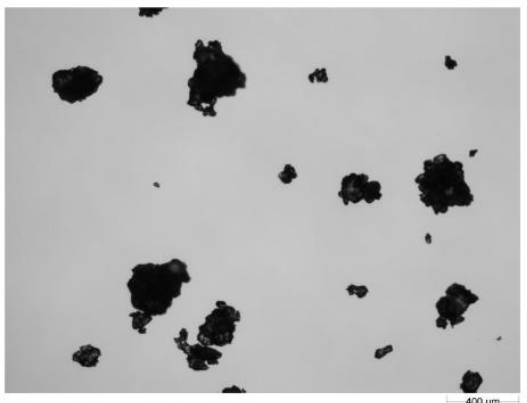

d)

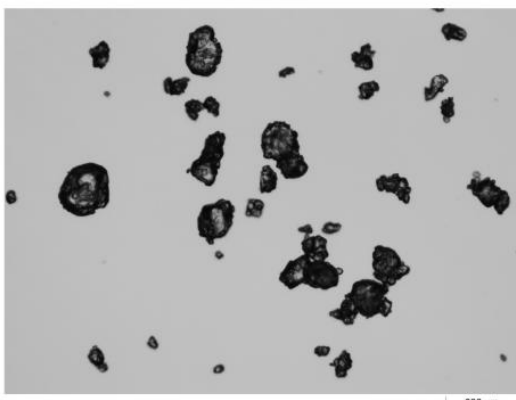

e)

Fig. 2. Microscopic images of selected granule samples: a) Sample 7_1, b) Sample 7_2, c) Sample 7_3, d) Sample 8_2, e) Sample 9_1.

phenomena was noticed with smaller quantities of Gra with comminuted sucrose (CS) (14.4 mL, Fig. 2 a, b, c). However, larger surface area allowed increased quantities of Gra to be used resulting in efficient granulation process with uniform nucleation and granule growth across different particle size ranges in the granulation bed and normal PSD of the granules in the granulate (Fig. $2 \mathrm{~d}$, e).

Decrease of BD has been observed when the bed is characterized with high level of granulation. In the samples where almost the whole raw material is granulated (CS granulated with higher quantities of Gra liquid) there is a lack of unprocessed raw material that could fill up the void spaces and therefore the BD is lower. The decrease in $\mathrm{BD}$ can be explained by the increase of the agglomerates size which results in an increase of the void spaces among the granules and lack of condensation (Heim et al., 2005). PLS analysis pointed to significant proportional influence of the raw material d50 upon the $\mathrm{BD}$ of the granules. TD followed the same pattern. It is evident that the density (bulk or tapped) decreases with decreasing d50 of the raw material and more efficient granulation when almost all raw material is granulated can be expected only for the samples with reduced size of the raw material for granulation. Higher amount of Gra, as well as higher Grn will produce granules with lower $\mathrm{BD}$ and $\mathrm{TD}$ for CS samples. Additionally, with the increase of the $\mathrm{BD}$ the compactibility of the granule fraction decreases. The
Table 2. VIP score list

\begin{tabular}{lc}
\hline Variables & VIP \\
\hline Drying time (min) & 1.52 \\
Granulation time (min) & 1.46 \\
Granulation liquid (g) & 1.43 \\
SLS (g) & 1.31 \\
S d90 & 1.31 \\
S d50 & 1.31 \\
S d10 & 1.11 \\
Impeler rate (rpm) & 1.11 \\
SPAN & 0.67 \\
Chopper rate (rpm) & 0.65 \\
\hline
\end{tabular}

deformation potential of the granules during compression depends on the porosity of the powder bed. A high deformation potential and high compactibility (high 
strength of the dosage form after compression and low diameter) can be obtained with lower $\mathrm{BD}$ value granules (Zuurman et al., 1994; van den Ban and Goodwin, 2017). Highly correlated variables and their influence upon the parameters of the granules are presented in Fig. 3, and variable importance or VIP score list is presented in Table 2.

The plot can be read by drawing a line from $\mathrm{Y}$ variable through the origin and across the plot. If the projected $X$ variables along this line are situated far away from the origin of the plot (on the positive or negative side) are highly correlated with $\mathrm{Y}$ and are most influential for the model. Variables located close to the origin are poor predictors of $\mathrm{Y}$ variables. $\mathrm{Y}$ variables close to each other, like TD and BD are positively correlated. The $\mathrm{X}$ variables situated close to $\mathrm{Y}$ variables are proportionally correlated to $\mathrm{Y}$ variables, and $\mathrm{X}$ variables located on the opposite side are reciprocally correlated to $\mathrm{Y}$ variables.

Significant reciprocal influence of the Gra and Grn was noticed for Carr index as well. Imp and d50 also influenced the Carr index but proportionally, or the higher the Imp and $\mathrm{d} 50$ of the raw material the higher the Carr index of the granulations.

The factor with highest influence upon the FR was the Dry. The correlation is proportional or the highest the
Dry, the highest the value of the FR or the lowest the flowability. The chopper rate during granulation has an opposite effect on the FR. Also, other factors like SLS quantity, granulation fluid quantity, granulation time showed inversely proportional correlation.

\section{Conclusion}

Among all other factors, there is a significant impact of the raw material properties on the final granule properties during the process of high share granulation. According to the variable importance or VIP scores, raw material particle size is as influential variable as the quantity and composition of the Gra, Grn and Imp. Small changes in the particle size and PSD of the starting sucrose as a raw material for granulation will induce changes in the efficacy of granulation and granule parameters. Having in mind that the maximum granule filling density that will permit efficient compaction is in a range of $0.6-0.7 \mathrm{~g} / \mathrm{cm} 3$ in order to manufacture granules with specific requirements, the $\mathrm{d} 50$ and $\mathrm{d} 90$ of the sucrose as raw material for high share granulation should be less than $90 \mathrm{~mm}$ and $200 \mathrm{~mm}$, respectively.

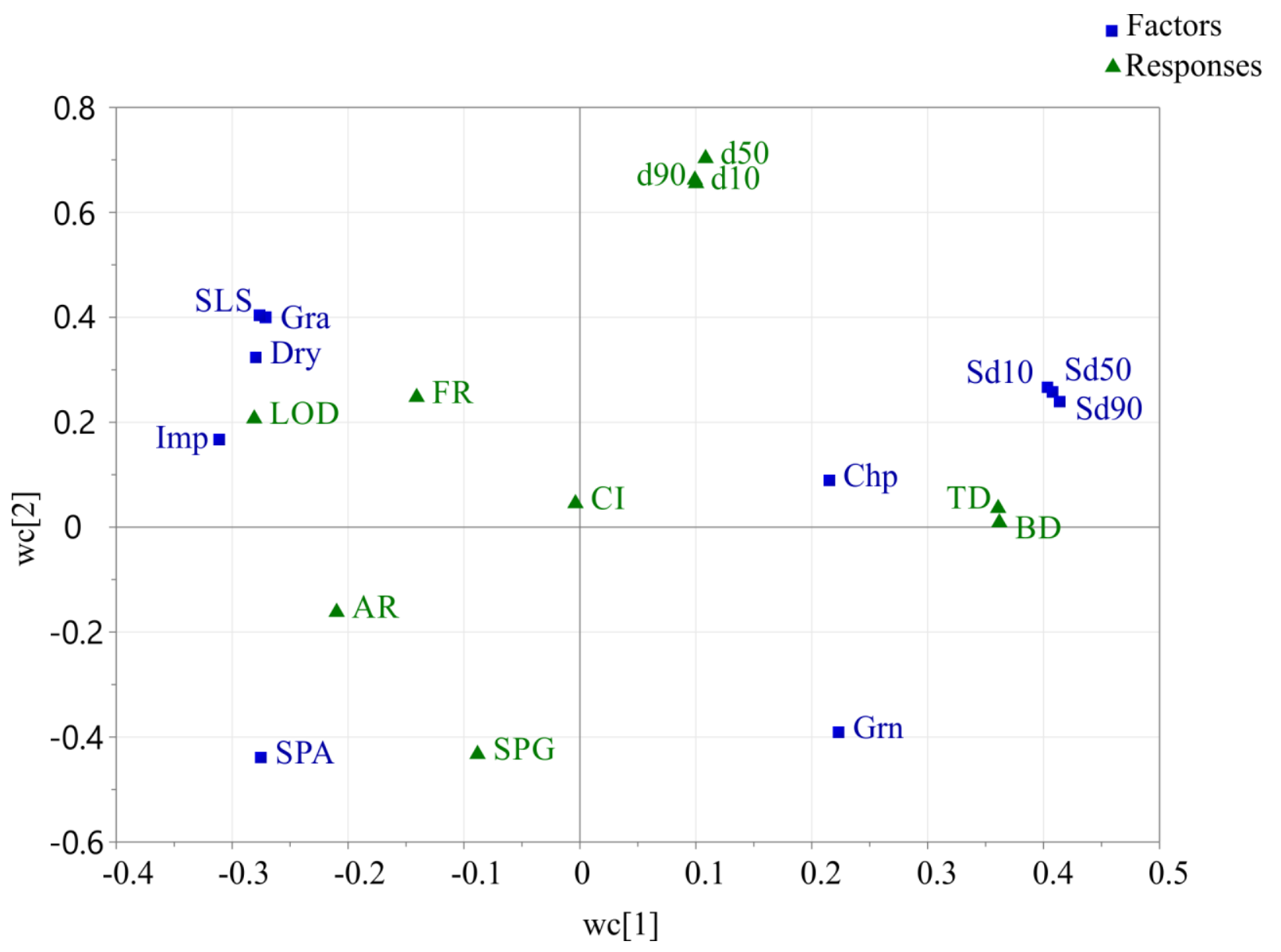

Fig. 3. Loadings scatter plot. 


\section{References}

Cavinato, M., 2008. High shear wet granulation: process understanding and scale up. $\mathrm{PhD}$ Thesis. University of Padova, Padova.

Cantor, S., Augsburger, L., Gerhardt, A., 2008. Pharmaceutical granulation processes, mechanism and the use of binders. In: Augsburger, L. L., Hoag, S. W. (Eds.), Pharmaceutical Dosage Forms - Tablets, Third Edition. CRC Press, Boca Raton, pp. 261-301.

Heim, A., Obraniak, A., Gluba, T., 2005. Changes of feed bulk density during drum granulation of bentonite. Physicochem. Probl. Miner. Process. 39, 219-228

Litster, J., Ennis, B., 2004. Wetting, nucleation and binder distribution. In: Litster, J., Ennis, B. (Eds), The Science and Engineering of Granulation Processes. Particle Technology Series, vol 15. Springer, New York, pp. 3774.

Miyamoto, Y., Ryu, A., Sugawara, S., Miyajima, M., Matsui, M., Takayama, K., et al. 1998a. Optimization of the granulation process for designing tablets. Chem. Pharm. Bull. (Tokyo). 46(9), 1432-1437.

Miyamoto, Y., Ogawa, S., Miyajima, M., Stoa, H., Takayama, K., Nagai, T., 1995. An evaluation of process variables in wet granulation. Drug. Dev. Ind. Pharm. 21(19), 22132225. Available at: https://doi.org/10.3109/03639049509065902.

Miyamoto, Y., Ryu, A., Sugawara, S., Miyajima, M., Ogawa, S., Matsui, M., et al. 1998b. Simultaneous optimization of wet granulation process involving factor of drug content dependency on granule size. Drug Dev. Ind. Pharm. 24(11), 1055-1065. Available at: https://doi.org/10.3109/03639049809089949.

Santomaso, A.C., Baggio, R., Zorzi, F., Salviulo, G., Realdon, N., Franceschinis, E., 2017. Sugars with different thickening power in high shear granulation. Powder. Technol. 15, 391-399. Available at: https://doi.org/10.1016/j.powtec.2017.05.017.

van den Dries, K., Vromans, H., 2004. Qualitative proof of liquid dispersion and penetration-involved granule formation in a high shear mixer. Eur. J. Pharm. Biopharm. 58(3), 551-559. Available at: https://doi.org/10.1016/j.ejpb.2004.04.012.

van den Ban, S., Goodwin, D.J., 2017. The impact of granule density on tabletting and pharmaceutical product performance. Pharm. Res. 34(5), 1002-11. Available at: https://doi.org/10.1007/s11095-017-2115-5.

Westerhuis, J.A., 1997. Multivariate statistical modelling of the pharmaceutical process of wet granulation and tableting. $\mathrm{PhD}$ Thesis. University of Groningen, Groningen.

Westerhuis, J.A., Coenegracht, P.M.J., 1997. Multivariate modelling of the pharmaceutical two-step process of wet granulation and tableting with multiblock partial least squares. J. Chemom. 11(5), 379-392. Available at: https://doi.org/10.1002/(SICI)1099128X(199709/10)11:5<379::AID-CEM482>3.0.CO;2-8.

Zuurman, K., Riepma, K.A., Bolhuis, G.K., Vromans, H., Lerk, C.F., 1994. The relationship between bulk density and compactibility of lactose granulations. Int. J. Pharm. 102, 1-9. Available at: https://doi.org/10.1016/03785173(94)90033-7. 


\title{
Определување на значајни фактори во процесот на влажна гранулација со мешалка со голема брзина на сахароза со воден раствор на натриум лаурил сулфат со користење на пристап со метод на најмали квадрати
}

\author{
Марина Тодоровска Ацковска ${ }^{1}$, Никола Гешковски ${ }^{2}$, Катерина Горачинова $^{2,3 *}$ \\ ${ }^{1}$ Оддел Производство Цефалоспорини, Алкалоид АД Скопје, Бул.Партизански Одреди \\ 98A, 1000 Скопје, Северна Македонија \\ ${ }^{2}$ Институт за фармацевтска технологија, Фармацевтски факултет, \\ Универзитет „Св. Кирил и Методиј”, Мајка Тереза 47, 1000 Скопје, \\ Северна Македонија \\ ${ }_{3}^{3}$ Фармацевтски колеи, Универзитет во Катар, поштенско сандаче 2713, Доха, Катар
}

Клучни зборови: сахароза, дистрибуција на честички според големина, влажна гранулација со мешалка со голема брзина (high-shear granulation), метод на најмали квадрати (partial least square)

Сахарозата како една од најчесто користените суровини во педијатриските формулации е растворлив и леплив ексципиенс, и нејзината манипулација во гранулатори со мешалка со голема брзина може да биде многу отежната. Затоа е многу важно да се определи точната количина на вехикулумот течноста за гранулирање бидејќи влегува во многу тесен опсег и може да варира поради малите варијации во карактеристиките на ексципиенсот или самите работни услови. Голем предизвик е можноста за користење на шеќерот за гранулација како шеќер во прав, поради растворливоста и апсорпцијата на влага како карактеристики на кристалниот шеќер, особено доколку течноста за гранулирање е вода. Целта на оваа студија е надминување на овие проблеми во процесот на влажна гранулација со мешалка со голема брзина и вода како течност за гранулирање и добивање на сахароза гранули со карактеристики неопходни за добар процес на добивање на финалниот производ. Со намалување на големината на честички на сахарозата и подобрување на униформноста на дистрибуцијата по големина, разликите во процесите на нуклеација и раст на гранулите за мали и големи честички може да се намалат. Според значајноста на променливите или ВИП резултатите од развиениот модел на метод на најмали квадрати, големината на честичките на ексципиенсот е значајна променлива како и количината и составот на течноста за гранулирање, времето на гранулирање и брзината на мешалката. 
